FASES E PERFIS CONSTRUTIVOS DA IGREJA NOSSA SENHORA DOS PRAZERES, PAULISTA, PE

FASES Y PERFILES CONSTRUCTIVOS DE LA IGLESIA NOSSA SENHORA DOS PRAZERES, PAULISTA, PE

CONSTRUCTIVE PHASES AND PROFILES OF THE NOSSA SENHORA DOS PRAZERES CHURCH, PAULISTA, PE

Mariana Freitas da Silva

Paulo Martin Souto Maior

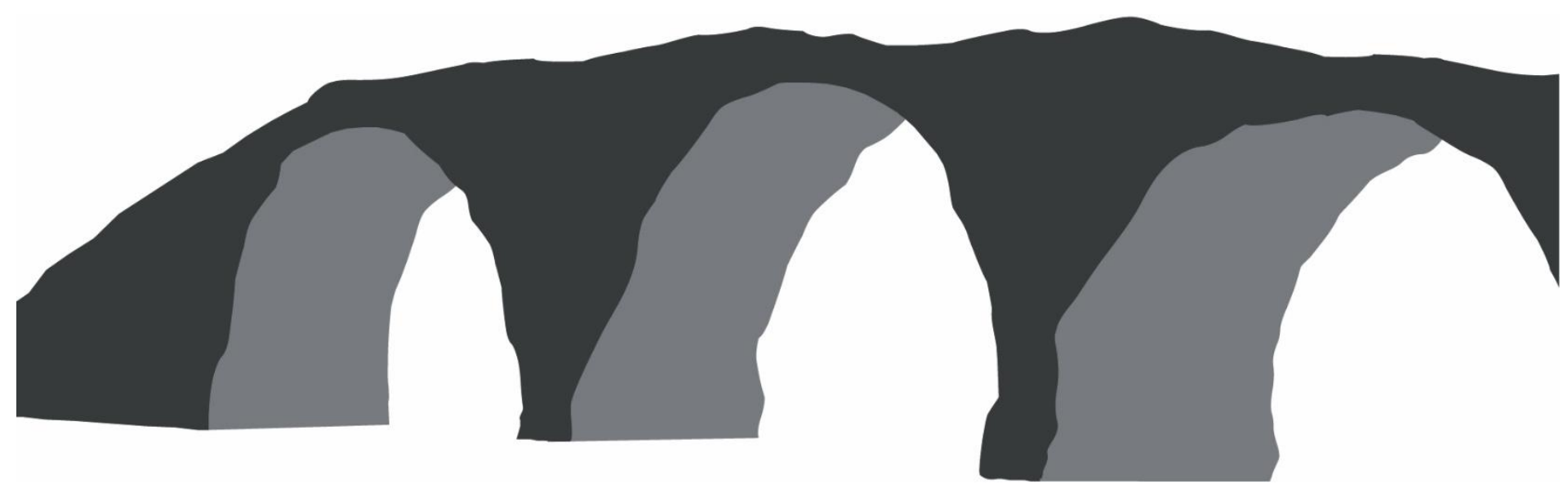




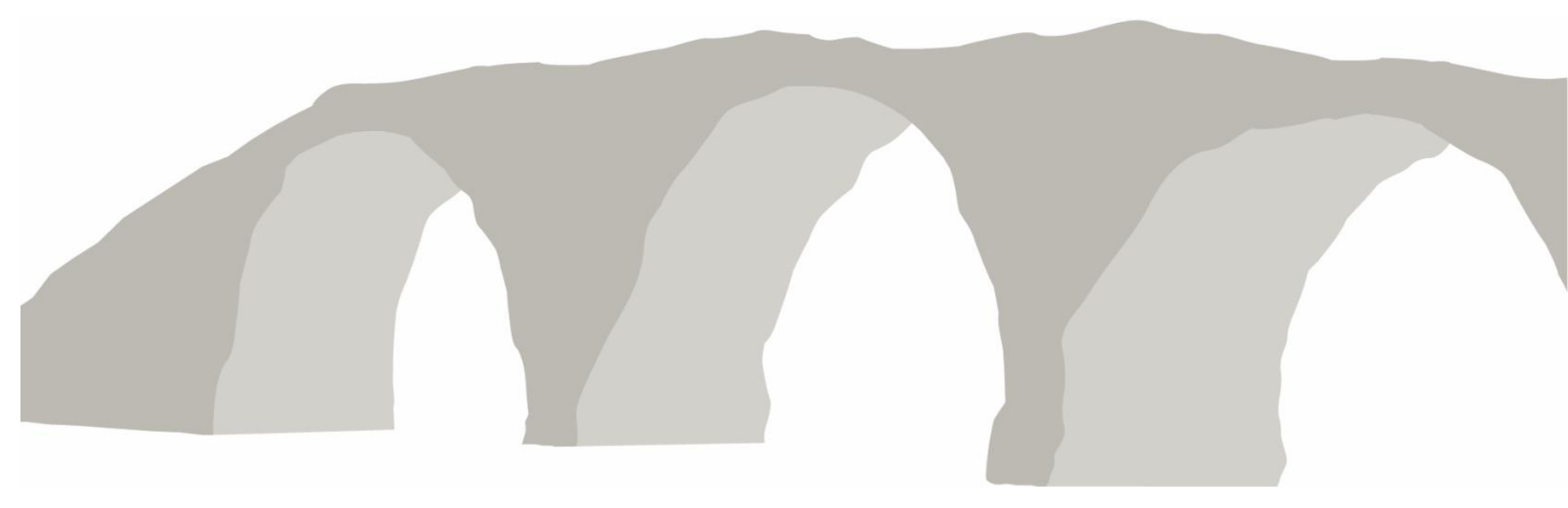

Submetido em 28/10/2019.

Revisado em: 23/07/2020.

Aceito em: 25/07/2020.

Publicado em 29/01/2021. 


\title{
FASES E PERFIS CONSTRUTIVOS DA IGREJA \\ NOSSA SENHORA DOS PRAZERES, PAULISTA, PE
}

\author{
FASES Y PERFILES CONSTRUCTIVOS DE LA IGLESIA \\ NOSSA SENHORA DOS PRAZERES, PAULISTA, PE
}

\section{CONSTRUCTIVE PHASES AND PROFILES OF \\ THE NOSSA SENHORA DOS PRAZERES CHURCH, PAULISTA, PE}

\author{
Mariana Freitas da Silva ${ }^{1}$ \\ Paulo Martin Souto Maior ${ }^{2}$
}

\begin{abstract}
RESUMO
A Igreja de Nossa Senhora dos Prazeres e sua Casa paroquial, localizadas em Maranguape II, no litoral Pernambucano, foram construídas, possivelmente, em 1656. Esta pesquisa teve como premissa básica identificar os fatores determinantes para a construção desses dois prédios em um território afastado da Vila de Olinda. Assim, a partir do ponto de vista quantitativo - através das composições mineralógicas dos tijolos cerâmicos, das rochas de cantaria e dos rejuntes - e qualitativo -através das paginações das alvenarias e da planta baixa -, chegou-se à identificação de três possíveis fases construtivas. O desafio maior foi associar os dados do levantamento físico e das fases construtivas aos contextos históricos e assim entender porque, em um período de instabilidade política, essas edificações foram construídas em uma área afastada do centro da antiga Vila de Olinda e quais as justificativas das ampliações e alterações nas técnicas construtivas e nas plantas baixas.
\end{abstract}

Palavras-chave: Nossa Senhora dos Prazeres, alvenarias históricas, perfis construtivos.

\footnotetext{
${ }^{1}$ Discente do Programa de Pós-graduação em Arqueologia da Universidade Federal de Pernambuco (UFPE).

E-mail: marianafreisi@gmail.com. ORCID: https://orcid.org/0000-0002-5481-1576.

${ }^{2}$ Professor do Departamento de em Arqueologia da Universidade Federal de Pernambuco (UFPE). E-mail: pmsmaior@yahoo.com.br. ORCID: https://orcid.org/0000-0003-1701-855X.
} 


\section{RESUMEN}

La iglesia de Nossa Senhora dos Prazeres y su casa parroquial, ubicada en Maranguape II, en la costa de Pernambuco, posiblemente fueron construidas en 1656. Esta investigación tuvo como premisa básica identificar los factores determinantes para la construcción de estos dos edificios en un territorio alejado del Pueblo de Olinda. Así, desde el punto de vista cuantitativo - a través de las composiciones mineralógicas de los ladrillos cerámicos, de la mampostería y del rejuntado - y desde el punto de vista cualitativo - a través del patrón de mampostería y la planta baja -, se identificaron tres posibles fases constructivas. El mayor desafío fue asociar los datos del levantamiento físico y las fases constructivas al contexto histórico y así entender por qué, en un período de inestabilidad política, estos dos edificios se construyeron en una zona alejada del centro de la antigua Vila de Olinda y cuáles fueron las justificativas de las ampliaciones y cambios en las técnicas constructivas y en sus plantas.

Palabras clave: Nossa Senhora dos Prazeres, mamposterías históricas, perfiles constructivos.

\section{ABSTRACT}

The Church of Nossa Senhora dos Prazeres and its Parish House, located in Maranguape II, on the coast of Pernambuco, were possibly built in 1656. This research aimed to identify the determining factors for the construction of these two buildings in a territory away from Olinda Village. Thus, from a quantitative point of view, through the mineralogical compositions of the ceramic bricks, stoneworks and grouts; and, from a qualitative point of view, through the masonry pattern and the blueprint, the study considers three possible construction phases. The greatest challenge was to associate the data from the physical survey and the construction phases to the historical contexts and, therefore, to understand why in a period of political instability those buildings were built in an area away from the center of the old Vila de Olinda and what the reasons for the expansions and changes in construction techniques and blueprints are.

Keywords: Nossa Senhora dos Prazeres, historical masonry, construction profile. 


\section{CONTEXTO HISTÓRICO}

João Fernandes Vieira teve papel fundamental na Restauração pernambucana que se deu durante a capitulação dos holandeses nas retomadas das terras pelos portugueses. Possivelmente, foi ele quem mandou construir a Igreja Nossa Senhora dos Prazeres, em 1656, em comemoração à retirada dos flamengos. Há indícios na documentação histórica que, após a Restauração de Pernambuco (1645-1654), João Fernandes Vieira, recebeu proventos em agradecimento aos serviços prestados à Coroa portuguesa e adquiriu várias outras propriedades em Pernambuco e Paraíba - entre as propriedades mencionadas em seu testamento, destacam-se as terras de Maranguape, ao norte de Olinda (Mello, 2000).

O poder religioso no período colonial também desempenhava um papel político, atuando, por exemplo, no controle de territórios. A Igreja era uma instituição subordinada ao Estado e a religião oficial funcionava como instrumento de dominação social, política e cultural (Azevedo, 2004). No caso da Igreja Nossa Senhora dos Prazeres, segundo Vieira (2010), há registros do séc. XVIII informando que ela se tornou Igreja matriz subordinada à Vila da Olinda em um período de inconstâncias políticas e econômicas que não justificava a criação de novas Freguesias.

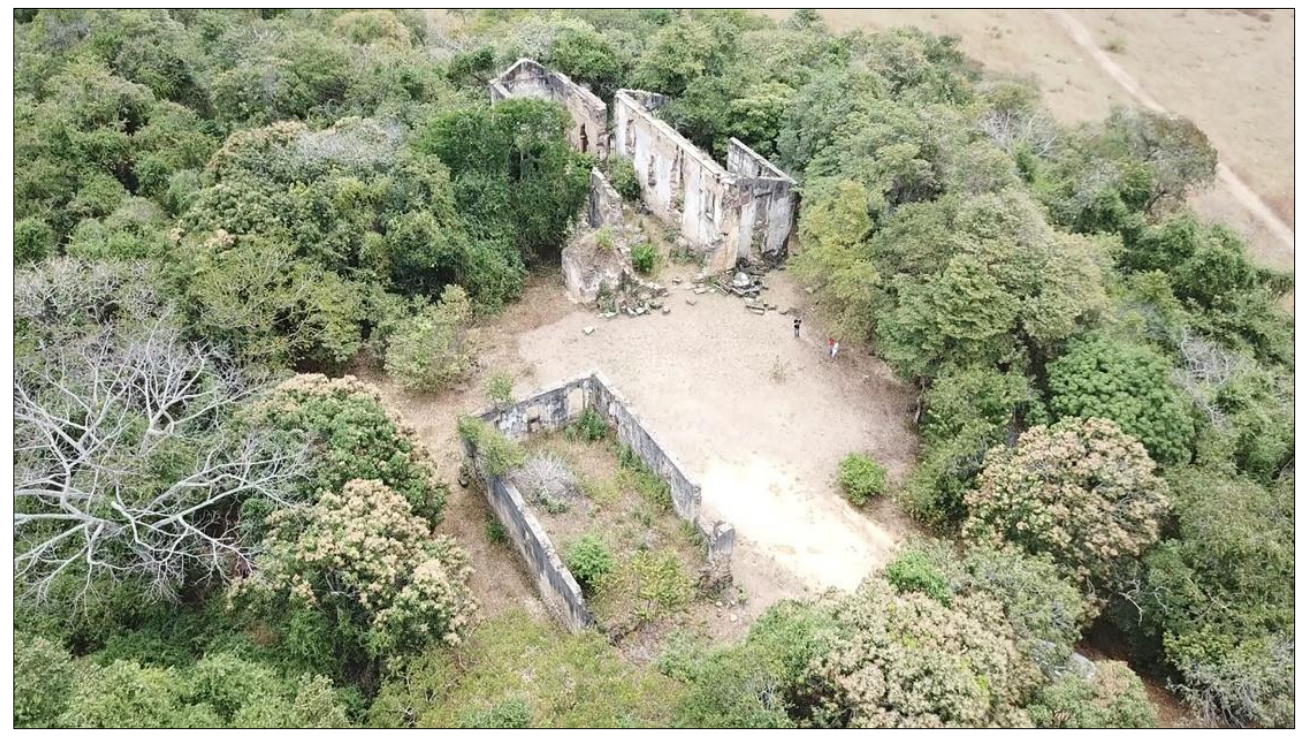

Figura 1. Vista aérea da Igreja de Nossa Senhora dos Prazeres e sua Casa paroquial. Fotografia da autora (2017).

Atualmente, na antiga Freguesia de Maranguape, restam ruínas da Casa paroquial e da Igreja Nossa Senhora dos Prazeres. Este trabalho utilizou essas ruínas junto a pouca documentação existente para conhecer as condições de fundação da Freguesia. Em face da relativa escassez desses documentos históricos, a análise dos materiais construtivos (tijolos, rejuntes, paginações) dessas ruínas permitiu estabelecermos fases de ampliações e reformas do prédio para que então pudessem ser associadas ao contexto histórico da região entre os séculos XVII e XVIII. Entretanto, inicialmente, o contexto histórico tinha lacunas que levaram a algumas indagações, as quais só puderam ser respondidas depois da análise material da edificação.

Entre essas indagações, cabe destacar: 
- Se o período (século XVII) era de instabilidade política, o que levou Fernandes Vieira homem de relevância social, a financiar a construção de uma Igreja em uma área afastada do centro da Vila de Olinda?

- Esse conjunto (Igreja e Casa paroquial) têm caráter construtivo unitário ou é produto de sucessivas reformas e modificações?

- Se houve ampliações e alterações nas técnicas construtivas e nas plantas baixas, quais foram os motivos?

- Há coerência entre as fases construtivas dessas edificações e momentos históricos da região?

Desse modo, para compreender as circunstâncias em que foi construída a Igreja e sua Casa paroquial, é necessário, antes, levarmos em consideração alguns acontecimentos: o papel da Vila de Olinda na economia da Capitania de Pernambuco (século XVII); e, posteriormente, seu declínio em função da invasão dos holandeses e da Guerra dos Mascates (século XVIII).

\section{A Vila de Olinda na eCONOmia da Capitania de Pernambuco entre os SÉculos XVII e XVIII}

Ao se estabelecer no Brasil com a política das Capitanias Hereditárias e com a ocupação das terras, Portugal tinha a agricultura como a principal atividade econômica, fator determinante para dar estabilidade à colônia (Schwartz, 1988). Apesar de todas as capitanias terem recebido mudas de cana-de-açúcar, nem todas conseguiram levar adiante sua produção - como o Espírito Santo, que, embora possuísse os recursos necessários para tornar o cultivo próspero, teve muitos engenhos destruídos pelos índios (Schwartz, 1988). Contudo, Pernambuco, com clima favorável e sob o comando de Duarte Coelho, conseguiu desenvolver a atividade de modo a prosperar economicamente a sociedade.

De 1580 a 1630, Pernambuco viveu um período próspero com a produção açucareira, uma vez que os engenhos passaram a dar mais lucros aos senhores, influenciando até mesmo o modo de vida da sociedade (Andrade, 2003). Com o crescimento da produção de açúcar, mais engenhos eram fundados e mais se notava o surgimento de outras atividades econômicas, como por exemplo: a fabricação de aguardente por proprietários de menores posses. Na mesma proporção do aumento da produção de açúcar, o número de escravos também crescia, para fazer frente ao cultivo voltado para exportação (Gomes, 1998).

O ciclo da cana-de-açúcar (final do século XVI e início do XVII) foi um divisor de águas no enriquecimento dos senhores de engenhos, que exportavam o produto, ao passo que outros tipos de cultivo de subsistência ficavam a cargo das pessoas de classes mais baixas (Andrade, 2003). A proibição do comércio da iguaria pelos espanhóis, durante a União Ibérica, causou um descontentamento aos holandeses, que buscavam alternativas para continuar com o controle da produção e venda do produto. A partir desses acontecimentos que prejudicaram economicamente a Holanda, em 1630 eles decidem invadir a capitania de Pernambuco. Com a presença holandesa em Pernambuco, em 1634, as terras da parte norte da capitania foram abandonadas devido a concentração das atividades econômicas e comerciais no Recife, deixando os engenhos inertes (Mello, 1976). A Igreja de Nossa Senhora dos Prazeres está localizada exatamente nessa parte, ao norte da capitania, e no período de sua construção, que se deu posteriormente à capitulação dos holandeses, a atividade produtora da região não tinha grande representação na economia de Pernambuco, o que reflete as políticas adotadas no período de 1630 a 1654.

A Restauração Pernambucana (1645-1654) foi um movimento importante contra a ocupação holandesa e contou com a participação dos habitantes da colônia e da força militar, sob a liderança de João Fernandes Vieira e André Vidal de Negreiros, que eram senhores de terra, comerciantes e militares (Mello, 2007). As 
lutas fomentaram o nativismo que já existia por parte dos olindenses, os quais buscavam por retomar suas atividades econômicas. Contudo, após a saída dos holandeses, a produção e a comercialização do açúcar passaram por um período de recessão, implicando a queda do preço de mercado. Diante disso, começa também a ocorrer o despovoamento de várias áreas, incluindo a Vila de Olinda (Mello, 2008).

Com a reconquista da capitania, a expectativa dos olindenses era de retomar suas atividades econômicas para promover o crescimento de Olinda, que foi interrompido pelos holandeses ao investirem recursos em Recife, com vistas a torná-la o centro econômico da capitania. A emancipação política e administrativa de Recife - que se deu, sobretudo, a partir de 1710, quando a cidade foi elevada à categoria de vila, chamada de Vila de Santo Antônio do Recife - causou uma tensão entre as duas cidades, motivada por disputa de poder. Diferentemente de Recife, Olinda não conseguiu progredir na mesma medida e essa disputa formou o seguinte cenário: de um lado, Olinda, onde residiam os nobres senhores de engenho, ligados à produção açucareira; e, do outro, Recife, onde estavam os comerciantes (chamados de forma injuriosa de mascates pelos senhores de engenho), banqueiros e financiadores da produção do açúcar (Nascimento, 2008, p. 174-175). .

Insatisfeitos com o crescimento econômico do Recife e almejando obter mais lucros e participações políticas e administrativas, os senhores de engenhos deram inícios aos conflitos econômicos conhecidas como Guerra dos Mascates (1710 - 1711), que nada mais foi que um movimento do poder político local contra os comerciantes portugueses de Recife. Assim, os acontecimentos ocorridos desde a invasão holandesa até a Guerra dos Mascates contribuíram para a formação política e social da capitania Pernambucana. A reconstrução da Vila de Olinda ocorreu lentamente após a Restauração Pernambucana (1645-1654) e a disputa com o açúcar produzido pelos holandeses nas Antilhas resultou uma queda econômica. Com o fracasso na guerra dos mascates, os problemas econômicos da Vila de Olinda ficaram ainda mais agravados, devido às invasões e incêndios nos engenhos. Na freguesia de Maranguape, lado Norte de Olinda, não foi diferente. Vários engenhos produtores de açúcar padeceram após o fracasso na luta contra Recife. A referida freguesia já estava em decadência desde a ocupação holandesa e, durante a Guerra dos Mascates, também teve seus infortúnios, propriedades invadidas e queimadas. No entanto, em detrimento da decadência de Olinda, a freguesia de Maranguape continuou a investir nos engenhos restantes e na produção de cal para o abastecimento de Recife (Vieira, 2010, p. 120).

\section{A FrEgUESIA DE MARANGUAPE}

Uma freguesia, quando era criada, tinha o poder administrativo delegado à vila da qual fazia parte. Mas, quando uma freguesia nascia com uma Igreja - como foi o caso da Igreja de Nossa Senhora dos Prazeres, já nascia com os poderes administrativos e religiosos associados à responsabilidade da Igreja. Uma freguesia, portanto, refletia duas coisas: primeiro, o aumento do controle sobre os moradores da localidade; e segundo, uma extensão territorial do poder administrativo (Mori, 1996, p. 27). No caso da Freguesia de Maranguape, há incertezas de onde sua história começou.

Após o falecimento de Fernandes Vieira, a Capela que atendia os moradores da região foi elevada à Curato 3 em 1691 pelo bispo Diocesano D. Matias de Figueredo e Melo (Araújo et al., 1993, p. 12). Em tempos

\footnotetext{
${ }^{3}$ Termo utilizado para indicar que uma aldeia ou povoado está apto a se tornar uma Freguesia.
} 
coloniais, quando uma Igreja era construída em uma zona distanciada da sede do bispado (exemplo de Olinda), era porque existia o interesse em atender os fiéis que viviam nas proximidades; assim como delimitar o território perante o Bispado (Vieira, 2010). Até o século XVIII, o poder religioso atuava paralelamente aos poderes econômicos e político, promovendo uma dominação territorial, por meio da organização de dioceses, paróquias e capelas; e do controle do monopólio religioso (Pereira, 2008).

Por alvará de D. João V, em 1719, Maranguape se tornou Freguesia e a Igreja Nossa senhora dos Prazeres foi elevada à categoria de Matriz, apesar das dificuldades financeiras de Olinda, decorrentes da invasão holandesa (1630-1654) e da Guerra dos Mascates (1710-1711). Assim, Olinda passou a possuir três Freguesias: a da Sé, a de São Pedro Mártir e a de Maranguape (Galvão \& Gomes, 2016, p. 75). É importante destacar que, nessa ocasião, a região norte de Olinda, onde a Freguesia de Maranguape estava situada, já não representava uma significativa contribuição econômica para a Capitania.

Para Santana (1993), a decadência da Igreja Matriz de Maranguape, na segunda metade do século XIX, ocorreu por causa do aumento de áreas de comércio mais próximas ao centro de Olinda; pelo fato de a Igreja estar mais perto de Recife; pelo aumento populacional em outras áreas próximas à cidade; e pela atuação da Igreja de N. Senhora do Ó, de Pau Amarelo, como Igreja Matriz.

No início do século XX, a Igreja de Nossa Senhora dos Prazeres já tinha sido vítima de arrombamentos, roubos e depredações por pessoas que estavam à procura de riquezas. Mas, o fim das suas atividades foi marcado por dois incêndios, ambos ocorridos na década de 1950. Em 1957, o Padre Norberto deixou um relato no livro de tombo ${ }^{4}$, que dizia que um grupo de cinco a seis homens bem armados invadiu a Igreja e fez grandes buracos em suas paredes. Assim, em abril de 1957, foram encerradas todas as atividades na Igreja matriz de Maranguape.

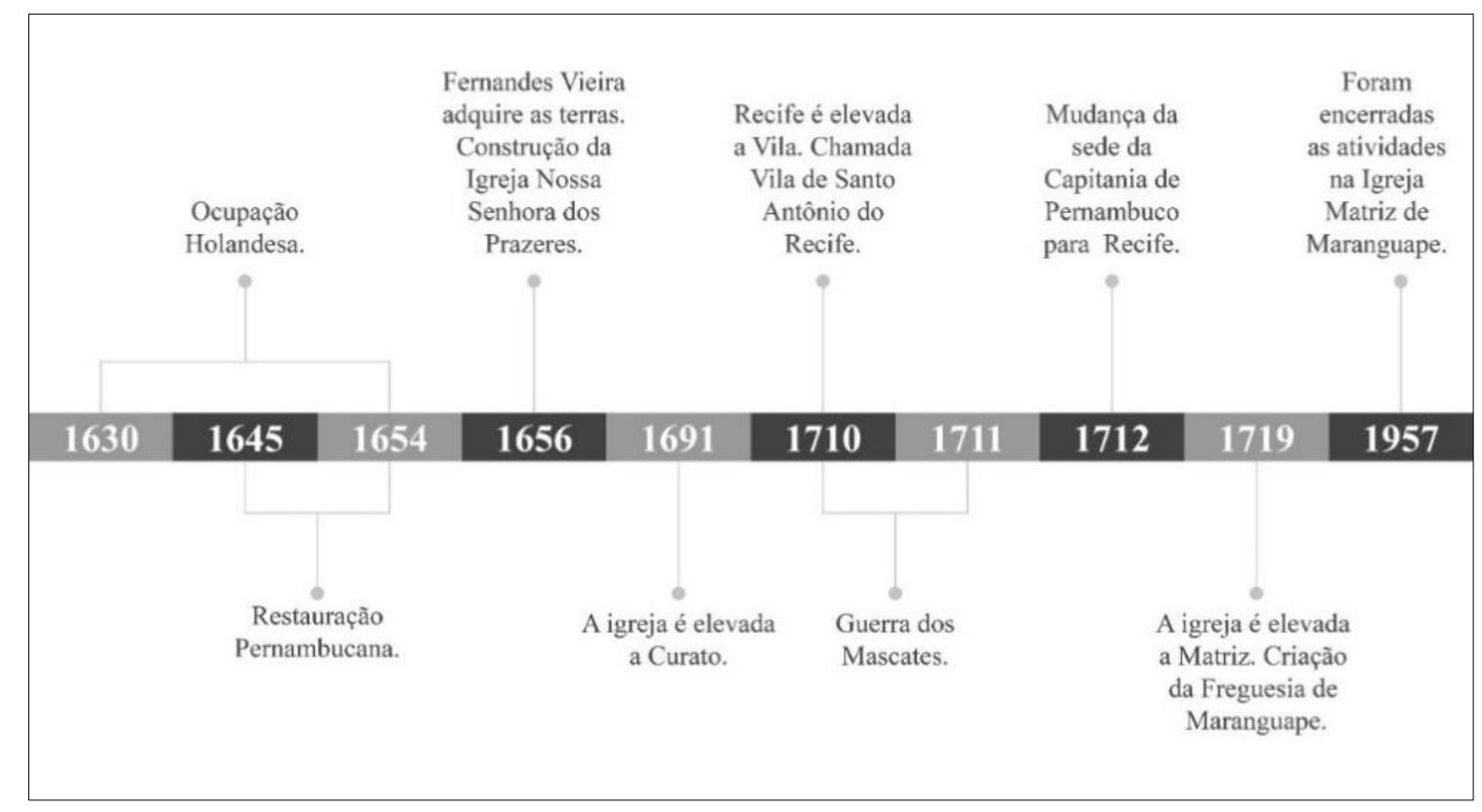

Figura 2. Eventos históricos que podem ser associados com fases construtivas (ampliações, reformas alterações) da Igreja Nossa Senhora dos Prazeres. Figura elaborada pela autora (2020).

${ }^{4}$ Hoje podem ser encontrados na Casa paroquial da Igreja Santa Isabel, localizada no centro de Paulista/PE. 


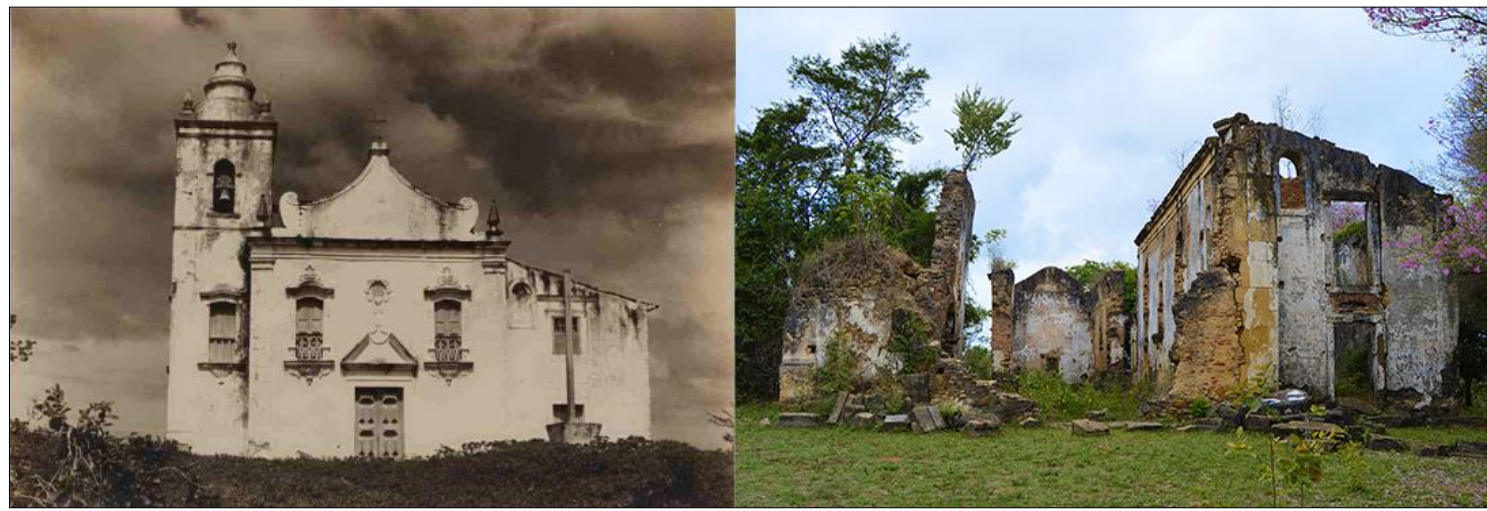

Figura 3. Fotografia da fachada frontal da Igreja de Nossa Senhora dos Prazeres em 1940 (Coleção de Benício Dias pertencente ao acervo de documentos fotográficos da FUNDAJ) e em 2017 (fotografia da autora).

\section{REFERENCIAIS CONCEITUAIS}

Na qualidade de cultura material, os edifícios históricos exemplificam as escolhas, conhecimentos práticos e técnicos do momento de sua construção até reformas realizadas a posteriori. A Igreja e a Casa paroquial são um exemplo tangível de um sistema de processamento de ideias colocadas em prática, que se concretiza na junção das matérias-primas em um determinado espaço. Compreender as relações que existem entre o bem material, o homem e seu espaço, pode revelar que o conhecimento construtivo, passado de forma consciente ou inconsciente, torna-se uma relevante variável para entender uma cultura (Lima Júnior, 2012).

Nesse cenário conceitual, os vestígios materiais deixados por grupos humanos podem ser divididos em trabalhos técnicos ou tecnológicos, como definem autores como Leroi-Gourhan, (1984), Basalla, (1990), Eiroa (1999), Lewis Munford, (1986), Vargas, (1994), Ruy Gama (1986); e a qualificação desses conceitos, diferencia-se quando se identificam as rupturas epistemológicas (Janeira, 1972).

Entretanto, esse foco em registrar perfis tecnológicos de uma fundação, de uma parede, de uma cúpula ou de uma coluna foi construído a partir do conceito de tectônica, Tektonik, em trabalhos como o de Karl Bötticher (1806-1889), Die Tektonik der Hellenen (A Tectônica dos Helenos), publicado pela primeira vez em 1844. O autor propôs uma definição para o termo como um processo de construção a partir das necessidades tanto do espírito humano quanto físicas; e não meramente tipos de estruturas construídas que utilizassem os materiais adequadamente. Nessa mesma linha, Handbuch der Archäologie der Kunst (Manual de Arqueologia da Arte), de Karl Otfried Müller, (1797-1840), publicado na segunda metade do século XIX, amplia o conceito e o aplica também a sistemas mecânicos, formas e construções que representassem os logros e as aspirações dos desejos do espírito humano, ou seja, o que poderíamos denominar de tecnologia artística utilitária.

Vale a ressalva que tékton, em grego clássico, significa carpinteiro, marceneiro, construtor de barcos, pedreiro, ferreiro, escultor, obreiro ou artesão em geral; mas pode designar também artista ou um mestre especialista. Por outro lado, tectônica vem de tektonikós, adjetivo derivado do verbo tektaínomai, que significa construir, fazer, entramar. Assim, pode significar algo referente à construção ou à habilidade de construir. Entretanto, tanto o substantivo tékton como o adjetivo tektonikós e o verbo tektaínomai compartilham a mesma raiz. Portanto, conceitualmente, tectônica sugere um rigor técnico e tecnológico atrelado a aspectos culturais e artísticos.

Em termos mais específicos e sob a ótica da identificação de perfis tecnológicos de estruturas arquitetônicas, curiosamente uma das publicações de maior visibilidade ao tratar exclusivamente sobre 
construção de prédios históricos, detendo-se à arte de sua construção ou à tectônica — embora sem citar o termo - , foi o artigo escrito pelo próprio Viollet, quem justamente estava no centro do debate sobre intervenção e restauração na segunda metade do século XIX. O texto Construction, publicado em 1859, é o mais extenso do Dictionnaire Raisonné de L'architecture, uma coleção dividida em dez volumes e publicada entre 1854 e 1875, que ocupou quase integralmente todo o quarto volume dedicado à tecnologia gótica medieval.

O marco definitivo seria dado em 1873, com L'art de Bâtir chez lês Romains, de Auguste Choisy. A intenção era outra. Não havia pretensões intervencionistas. A motivação maior para a construção da metodologia foi a constatação de que as edificações históricas, especificamente na Itália e durante sua visita a Roma, entre 1866 e 1867, eram estudadas apenas a partir de seus aspectos arquitetônicos. E naquela época, a palavra arquitetônico restringia-se ou tendia-se nas palavras do próprio A. Choisy (1999, p. 23) “(...) às análises que ficam na superfície dos monumentos sem chegar na estrutura pois”, acrescenta, “(...) conhecemos todavia de maneira muito vaga seus procedimentos construtivos".

Os trabalhos de Choisy foram um divisor de águas. Intervenção, restauração e monumento são, quando citados, temas completamente secundários. O autor se preocupou em entender o comportamento mecânico e até as evidências dos processos técnicos e tecnológicos através dos vestígios materiais como resultado de um traço cultural. A referência era o que havia sobrevivido e que era palpável e fisicamente analisável sem nenhuma vinculação simbólica, típica daquelas atribuídas a grandes prédios públicos, os quais se denominavam monumentos. Seus livros posteriores - L'art de Bâtir chez lês Bizantin (A Arte de Construir em Bizâncio), publicado em 1884; e L'art de Bâtir chez lês Ėgyptiens (A Arte de Construir no Egito), publicado em 1904 - consolidaram uma metodologia de classificação de vestígios do passado com base em evidências materiais, portanto, uma postura arqueológica. E não há concessão em seus textos. Não são feitas retrospectivas históricas, nem tenta inserir os vestígios em momentos estilísticos, muito menos proposituras intervencionistas. Classifica, cataloga e agrupa na tentativa de registrar o que hoje se define por tectônica. Portanto, o que autores definem hoje como arqueologia da arquitetura é, na verdade, uma espécie de título novo para um tema antigo. Atualmente, no máximo, se utilizam ferramentas de coleta de dados mais precisos, mas a origem, como se viu, é bem anterior.

Assim, identificar, através do vestígio material, como foi feito (a técnica); quais as transformações (a tecnologias); e sob que circunstâncias (contexto); foi o maior objetivo desta pesquisa. Portanto, qualificar uma edificação, é compreender a cadeia operatória do edifício e seus materiais. O desafio deste estudo foi desenvolver um método que permitisse identificar se houve o uso de tecnologia ou repetições de processos conhecidos na construção da Igreja de Nossa Senhora de Maranguape e sua Casa paroquial; e, ainda, relacionar isso ao seu contexto histórico político, religioso e social. A sistematização do processo nos levantamentos qualitativos e quantitativos foi necessária para que não sofressem influências externas, comprometendo os resultados. Com a realização das análises, é possível conhecer as técnicas construtivas do edifício e a composição dos materiais.

\section{LEVANTAMENTO QUANTITATIVO E QUALITATIVO DAS EDIFICAÇÕES}

\subsection{LEVANTAMENTO QUANTITATIVO DOS VESTÍGIOS MATERIAIS}

Para realizar o levantamento físico dos edifícios, utilizou-se uma trena de fita para as medições do comprimento da extensão e espessura das paredes, dos materiais (tijolo, rocha e rejuntes), bem como também 
o comprimento e a largura de todos os cômodos. A partir dos dados coletados das medidas da Igreja e Casa paroquial, foi possível realizar a representação gráfica de ambos os edifícios, que passaram a ser representados a partir de desenhos de toda sua estrutura.

Para conhecer cada alvenaria e os materiais utilizados, foi necessário, após a elaboração da representação gráfica dos edifícios, realizar o levantamento das paginações, que podem indicar tipos de alvenarias existentes. Todos os procedimentos que aqui serão mencionados foram realizados em todas as paredes da Igreja e Casa paroquial.

Após a verificação das espessuras das 14 paredes da Igreja e das 4 paredes da Casa paroquial, foi percorrida toda a área das 2 estruturas em busca de variações nas alvenarias. O levantamento foi realizado medindo a extensão linear da alvenaria a cada mudança das suas características físicas. Para cada trecho de parede da Igreja e da Casa paroquial, foram feitos registros imagéticos com fotografias e o registro métrico de cada mudança. Em cada alvenaria identificada, como pode ser visto nas figuras 4 e 5 , foram realizados o mesmo processo de coleta de dados com os mesmos instrumentos.

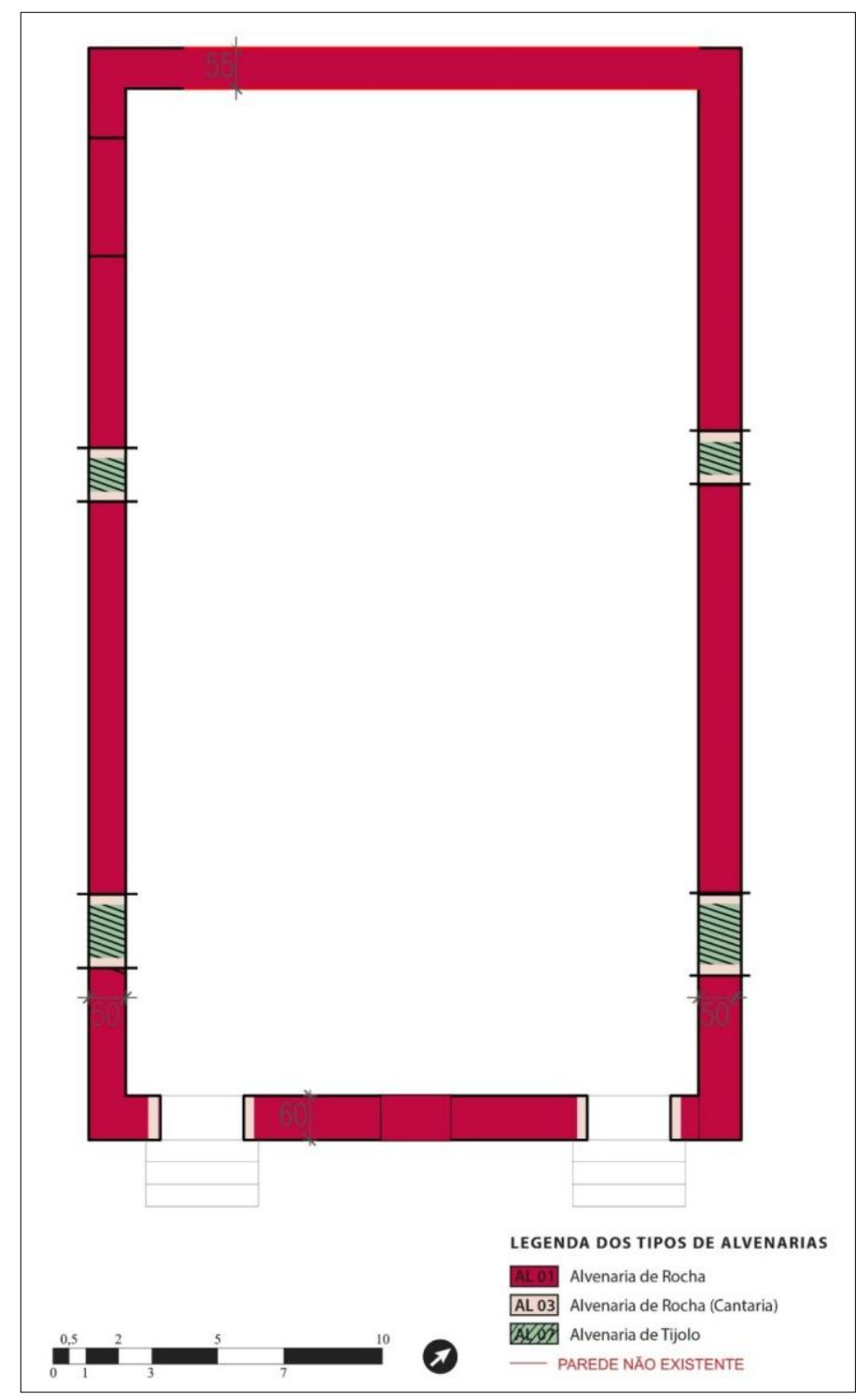

Figura 4. Identificação e qualificação das paredes da Casa paroquial a partir dos tipos de alvenarias. Figura elaborada pela autora (2018). 


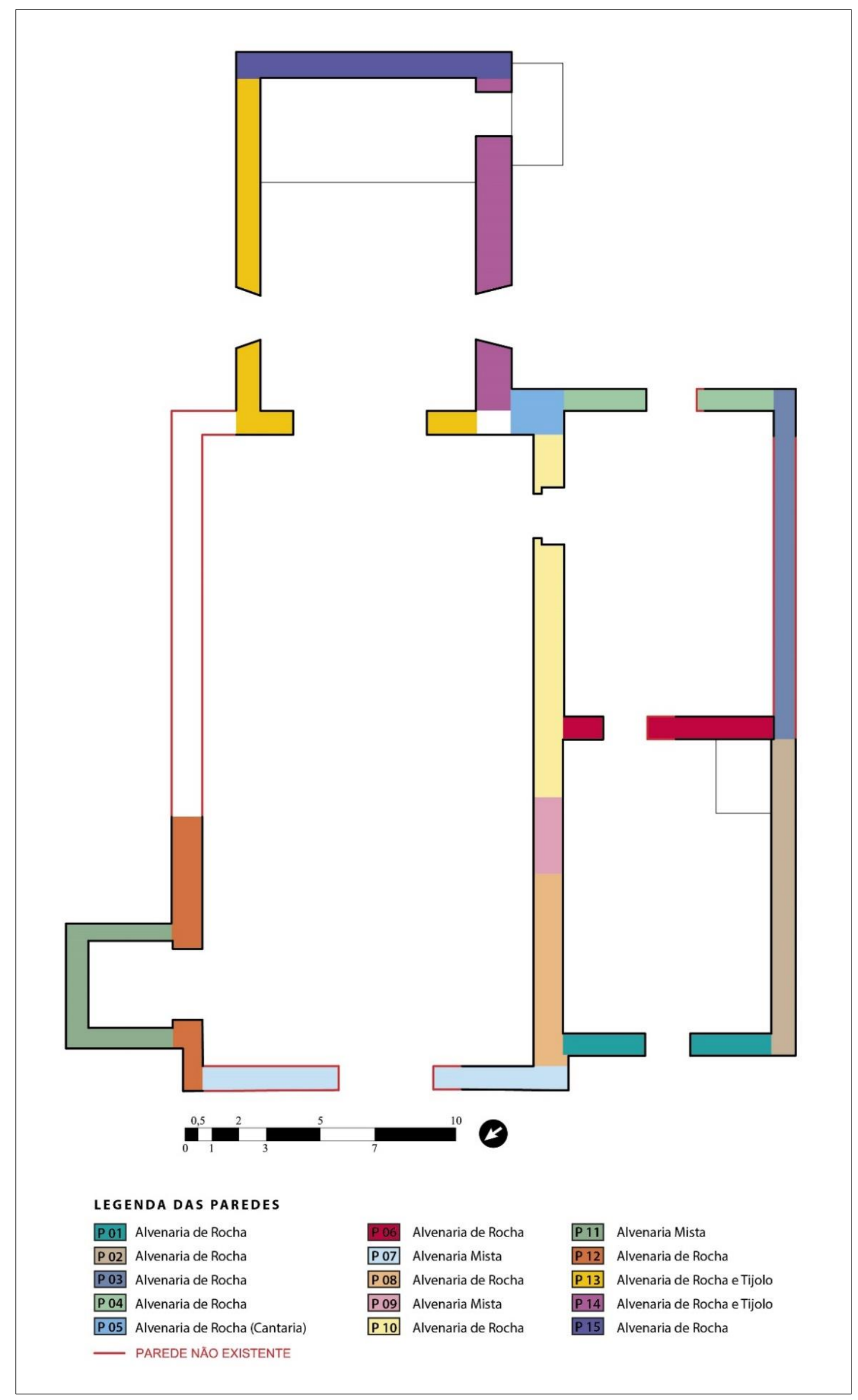

Figura 5. Identificação e qualificação das paredes da Igreja a partir dos tipos de alvenarias.

Figura elaborada pela autora (2018). 


\subsection{LEVANTAMENTO QUALITATIVO DOS PERFIS TÉCNICOS}

Sobre cada material que compõem o edifício, as análises tiveram início com os tijolos, em que se observou a aparência na sua forma geral e na sua integridade. O tijolo possui faces e arestas, sendo a face um dos lados do tijolo e a aresta, as linhas que separam as faces. Cada unidade possui 6 faces e 8 arestas. Na dimensão, o tijolo é formado pelo comprimento, altura e espessura, que são determinados a partir da utilização de uma trena metálica. Todas as medidas devem ser realizadas de uma extremidade à outra. A coloração é observada de forma direta ao material em sua superfície (Matos, 2009).

A partir da classificação prévia de todos os tijolos observados nas paredes, foi possível resumi-los em uma nova classificação, considerando principalmente o formato e a aparência das unidades medidas. No caso da Igreja e da Casa paroquial, verificou-se a existência de dois tipos de tijolos, denominados como tipo 1 e tipo 2. O tipo 1 se refere a tijolos que possuem coloração vermelho escuro; têm medidas que variam no comprimento de 27 a $31 \mathrm{~cm}$, na largura de 12 a $16,5 \mathrm{~cm}$ e na espessura de 4 a $6 \mathrm{~cm}$; não possuem arestas; têm formato retangular irregular; e possuem fraturas ou estão íntegros. Já os tijolos tipo 2 apresentam uma coloração vermelho claro; formato retangular regular; íntegros e enrugados; e com arestas. Porém, os tijolos desse tipo estão nas paredes mais altas do altar mor e, por isso, foi possível medir somente algumas unidades da parede. As observações evidenciaram que na Igreja é possível encontrar os tijolos tipo 01 e tipo 02 e na Casa paroquial somente o tipo 01, de forma pontual apenas embaixo das janelas.

Nas rochas, foi observado o acabamento de superfície para identificar se recebeu tratamento ou se está em sua forma bruta. As dimensões são o seu comprimento, altura e espessura. As rochas podem variar nos formatos e podem ser classificadas em: quadrangular, linear, poligonal, arredondado e em seu estado natural (Mannoni, 2005).

Assim, de forma a reduzir o campo de observação, as rochas existentes na estrutura foram classificadas em três tipos: tipos 01, 02 e 03. No tipo 01, as rochas apresentaram uma variação de tamanho: para rochas menores, de 06 a 17,5 cm; para as médias, de 19 a $37 \mathrm{~cm}$; e as maiores, de 44,5 a $70 \mathrm{~cm}$. No tipo 02, também foi encontrada uma variação: para as rochas menores, de 7 a $19 \mathrm{~cm}$; para as médias, de 28 a $36 \mathrm{~cm}$; e para as maiores de 56 a $67 \mathrm{~cm}$. E, as rochas do tipo 03, possuem as seguintes dimensões: $90 \mathrm{~cm}$ de comprimento, e uma variação de 30 a 44 cm de altura, já que esse tipo se refere a rochas em cantaria. Nas paredes 06, 07, 09, 11,13 e 14, pode ser observada a presença das rochas tipo 01 e tipo 02.

Nas argamassas, foram observadas as dimensões das juntas - espaços entre os materiais presentes na parede, rocha ou tijolo -, que podem estar dispostas horizontalmente ou verticalmente. A disposição das juntas verticais, que contribuem para a estabilidade e resistência das paredes, indica-se que seja colocada de forma que os materiais possuam uma amarração entre si, onde as juntas precisam estar bem posicionadas em cima de cada unidade de material (Matos, 2009).

\subsubsection{Perfis técnicos da Igreja}

A partir das observações das características dos materiais, verificou-se a existência de quatro tipos de paginação presentes em todas as estruturas: 


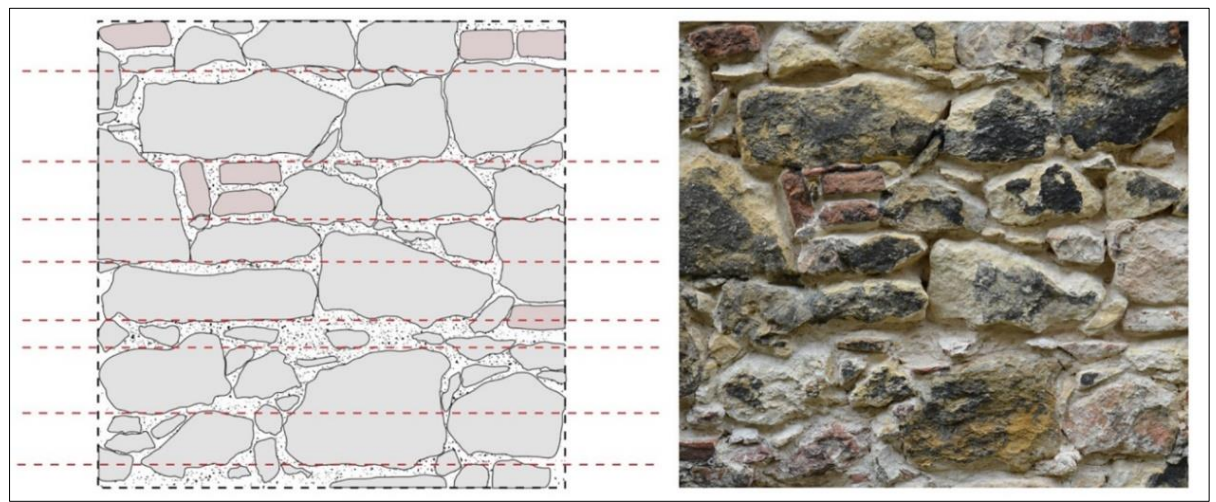

Figura 6. Representação e fotografia da paginação tipo 01, a parede 13 exemplifica esta unidade. Nessa alvenaria as rochas maiores foram assentadas em fiadas horizontais, que podem ter ou não tratamento de superfície, perceptíveis a olho nu, e que mostram uma tendência ao alinhamento dos materiais. Os espaços vazios foram preenchidos por rochas menores e que não possuem tratamento de superfície. Os tijolos aparecem de forma aleatória, apenas para preencher espaços vazios.

Fotografia e figura elaborada pela autora (2018).

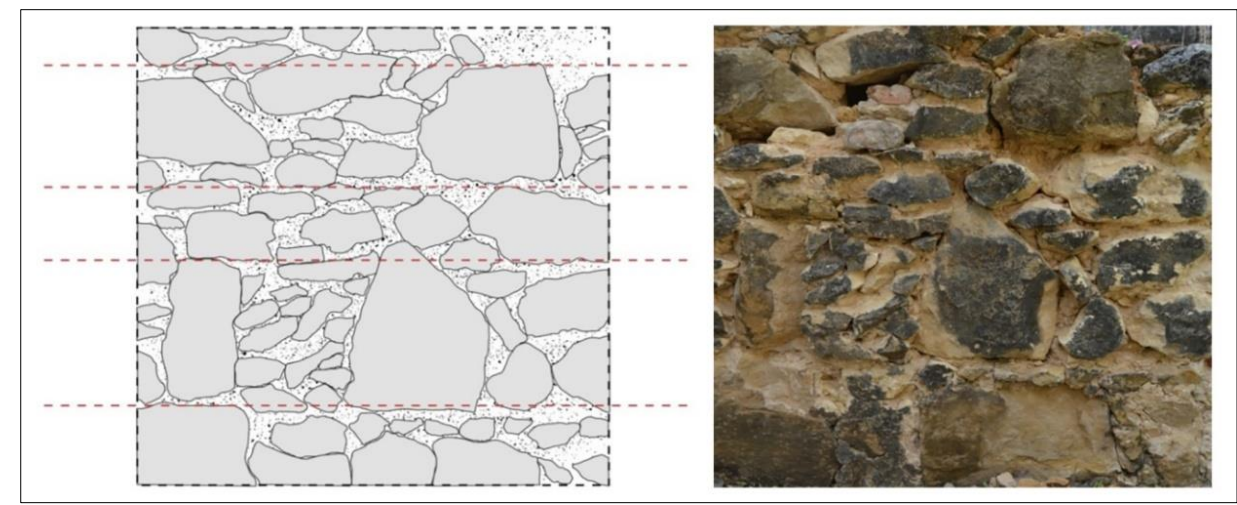

Figura 7. Representação e fotografia da paginação tipo 02, a parede 6 exemplifica esta unidade. Nessa alvenaria as rochas maiores foram assentadas em fiadas horizontais na base da parede, porém toda a sua continuidade aparenta um emaranhado de materiais construtivos, não respeitando a horizontalidade. As rochas menores ocupam os espaços vagos, não obedecendo a uma ordem. Os espaços vazios foram preenchidos por rochas menores e que não possuem tratamento de superfície Fotografia e figura elaborada pela autora (2018).

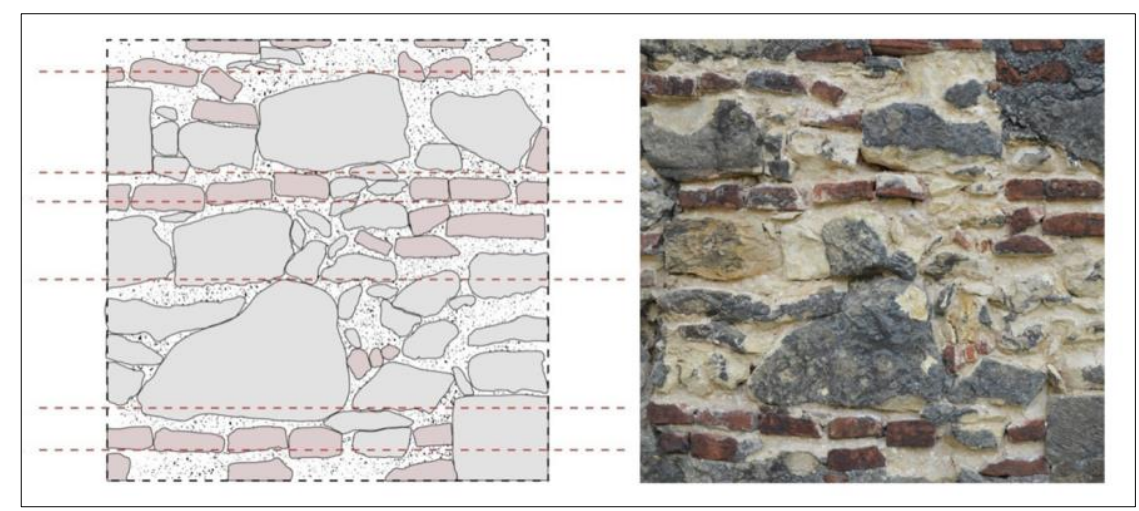

Figura 8. Representação e fotografia da paginação tipo 03, a parede 07 exemplifica esta unidade. Nessa alvenaria as rochas maiores foram assentadas em fiadas horizontais, que podem ter ou não tratamento de superfície, perceptíveis a olho nu, e que mostram uma tendência ao alinhamento dos materiais. Os espaços vazios foram preenchidos por rochas menores e que não possuem tratamento de superfície. Os tijolos também são assentados em fiadas horizontais seguindo o alinhamento das rochas maiores. Fotografia e figura elaborada pela autora (2018). 


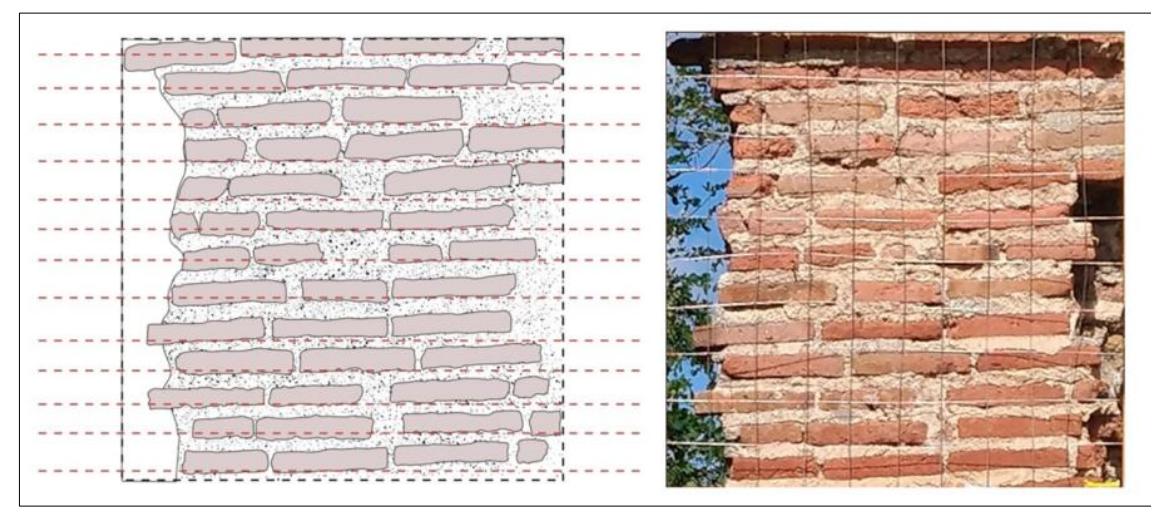

Figura 9. Representação e fotografia da paginação tipo 04, a parede 13B (B - significa que está localizado na parte mais alta da parede) exemplifica esta unidade. Nessa alvenaria os tijolos foram assentados em fiadas horizontais, com tijolos inteiros e quebrados, com uma variação nas disposições das juntas de 2 a 4,5 cm. Essa alvenaria está presente, apenas, no altar mor e na nave central e não possui presença de rochas. Fotografia e figura elaborada pela autora (2018).

Tabela 1. Tipos de paginação da Igreja de Nossa Senhora dos Prazeres e da Casa paroquial. Elaborada pela autora (2018).

\begin{tabular}{|c|c|c|c|c|c|}
\hline PAGINAÇÃO & FUNÇÃO & $\begin{array}{c}\text { ORGANIZAÇÃO } \\
\text { HORIZONTAL }\end{array}$ & $\begin{array}{c}\text { DISTÂNCIA } \\
\text { VERTICAL } \\
\text { NÍVEIS } \\
\text { DIFERENTES }\end{array}$ & $\begin{array}{c}\text { REPETIÇÃO DA } \\
\text { DISTÂNCIA } \\
\text { HORIZONTAL } \\
\text { EM NÍVEIS } \\
\text { DIFERENTES }\end{array}$ & $\begin{array}{c}\text { PRESENÇA DE } \\
\text { TIJOLO } \\
\text { (INTEGRIDADE) }\end{array}$ \\
\hline Paginação 1 & $\begin{array}{c}\text { Parede } \\
\text { estrutural } \\
\text { (externa) }\end{array}$ & Em Linha horizontal & $\begin{array}{l}\text { Variada e } \\
\text { contato }\end{array}$ & Não & - \\
\hline Paginação 2 & $\begin{array}{c}\text { Parede } \\
\text { estrutural } \\
\text { (interna) }\end{array}$ & Emaranhado & $\begin{array}{l}\text { Variada e } \\
\text { Contato }\end{array}$ & Não & - \\
\hline Paginação 3 & $\begin{array}{c}\text { Parede } \\
\text { estrutural } \\
\text { (externa) } \\
\end{array}$ & $\begin{array}{c}\text { Em linha horizontal } \\
\text { e emaranhado }\end{array}$ & $\begin{array}{l}\text { Variada e } \\
\text { contato }\end{array}$ & Não & $\begin{array}{c}\text { Pedaços e com } \\
\text { presença de inteiros }\end{array}$ \\
\hline Paginação 4 & $\begin{array}{c}\text { Estrutural } \\
\text { externa }\end{array}$ & Em linha horizontal & 2 a $4,5 \mathrm{~cm}$ & Sim & Inteiros e pedaços \\
\hline
\end{tabular}

Com a identificação dos 4 tipos de paginação de alvenarias, fez-se necessário objetivar a pesquisa levando em consideração as características de cada uma dessas alvenarias. Sendo assim, alguns fatores foram necessários para essa seleção. Com os tipos de materiais identificados e os de tipos de paginação, foi necessário realizar o cruzamento dos dados para observar a existência da relação entre as alvenarias. Para conferir essa relação, foi observado em cada parede os tipos de materiais utilizados e a paginação e, a cada novo formato de organização das paredes, novas alvenarias eram identificadas. Desse modo, observou-se as alvenarias que se mostraram mais relevantes, por apresentar uma maior repetição nas estruturas, e apenas as alvenarias estruturais.

Após a observação das características de cada parede, foi observado que os dois tipos de tijolo mais os três tipos de rochas e as quatro paginações resultaram em sete alvenarias existentes nos dois prédios aqui trabalhados. A Tabela 3 evidencia essa classificação de forma simplificada. 
Tabela 2. Associação dos tipos de materiais e da paginação em cada parede da Igreja de Nossa Senhora dos Prazeres e da Casa paroquial. Elaborada pela autora (2018).

\begin{tabular}{|c|c|c|c|}
\hline \multirow{2}{*}{ PAREDE } & \multicolumn{2}{|c|}{ TIPOS DE MATERIAL CONSTRUTIVO } & \multirow{2}{*}{$\begin{array}{c}\text { TIPOS DE } \\
\text { AGENCIAMENTO }\end{array}$} \\
\hline & TIJOLO & ROCHA & \\
\hline PAREDE 01 & - & Tipo 01 & Paginação1 \\
\hline PAREDE 02 & - & Tipo 01 & Paginação1 \\
\hline PAREDE 03 & - & Tipo 02 & Paginação1 \\
\hline PAREDE 04 & Tipo 01 (porta) & Tipo 01 & Paginação1 \\
\hline PAREDE 05 & - & Tipo 03 (Cantaria) & Paginação1 \\
\hline PAREDE 06 & - & Tipo 01 e 02 & Paginação2 \\
\hline PAREDE 07 & - & Tipo 01 e 02 & Paginação3 \\
\hline PAREDE 08 & - & Tipo 01 & Paginação1 \\
\hline PAREDE 09 & Tipo 01 & Tipo 01 e 02 & Paginação3 \\
\hline PAREDE 10 & - & Tipo 01 & Paginação1 \\
\hline PAREDE 11 & Tipo 01 & Tipo 01 e 02 & Paginação3 \\
\hline PAREDE 12 & Tipo 01 & Tipo 01 & Paginação1 \\
\hline PAREDE 13 B cima & Tipo 02 & - & Paginação4 \\
\hline PAREDE 13 A baixo & Tipo 01 & Tipo 01 e 02 & Paginação1 \\
\hline PAREDE 14 & Tipo 01 & Tipo 01 e 02 & Paginação1 \\
\hline PAREDE 15 & - & Tipo 01 & Paginação1 \\
\hline C.PAROQUIAL & Tipo 01 & Tipo 01 & Paginação1 \\
\hline
\end{tabular}

Tabela 3. Associação dos tipos de materiais e da paginação a cada parede da Igreja de Nossa Senhora dos Prazeres e da Casa paroquial. Elaborada pela autora (2018).

\begin{tabular}{cc}
\hline TIPO DE ALVENARIA & PAREDES DA IGREJA E CASA PAROQUIAL \\
\hline AL 01 & $\begin{array}{c}\text { Parede 01, Parede 02, Parede 04, Parede 08, } \\
\text { Parede 10, Parede 12, Parede 15, Casa Paroquial }\end{array}$ \\
\hline AL 02 & Parede 03 \\
\hline AL 03 & Parede 05 \\
\hline AL 04 & Parede 06 \\
\hline AL 05 & Parede 07, Parede 09, Parede 11 \\
\hline AL 06 & Parede 13 A baixo, Parede 14 \\
\hline AL 07 & Parede 13 B cima \\
\hline
\end{tabular}

A escolha das alvenarias deve propiciar o reconhecimento das técnicas construtivas realizadas na Igreja e na Casa paroquial, bem como os materiais utilizados. Para esta seleção, a alvenaria foi calculada em metros lineares, considerando todas as suas extremidades. Desse modo, somou-se as distâncias de todas as paredes que compõe cada alvenaria aqui definida. Os resultados obtidos a partir desse cálculo são apresentados na tabela 4 a seguir. 
Tabela 4. Quantidade em metros lineares presentes da Igreja nossa senhora dos prazeres e da Casa paroquial. Elaborada pela autora (2018).

\begin{tabular}{c|c|c}
\hline \multirow{2}{*}{ ALVENARIA } & \multicolumn{2}{|c}{$\begin{array}{c}\text { QUANTIDADE DE ALVENARIA EM } \\
\text { METROS LINEARES }\end{array}$} \\
\cline { 2 - 3 } & METRO & $\mathbf{\%}$ \\
\hline AL 01 & 83,94 & $53 \%$ \\
\hline AL 02 & 8,42 & $5 \%$ \\
\hline AL 03 & 0,9 & $1 \%$ \\
\hline AL 04 & 5,2 & $3 \%$ \\
\hline AL 05 & 20,46 & $13 \%$ \\
\hline AL06 & 24,74 & $15 \%$ \\
\hline AL 07 & 16,17 & $10 \%$ \\
\hline TOTAL & $\mathbf{1 5 9 , 8 3}$ & $\mathbf{1 0 0 \%}$ \\
\hline
\end{tabular}

Com base nos dados apresentados, apenas quatro tipos de alvenarias possuem mais de 10 metros lineares e, por estarem na maior parte das estruturas, somente elas foram escolhidas para análises mais minuciosas. Sendo assim, as alvenarias escolhidas foram: AL 01, AL 05, AL 06, AL 07, como se pode observar na figura 10 a seguir.

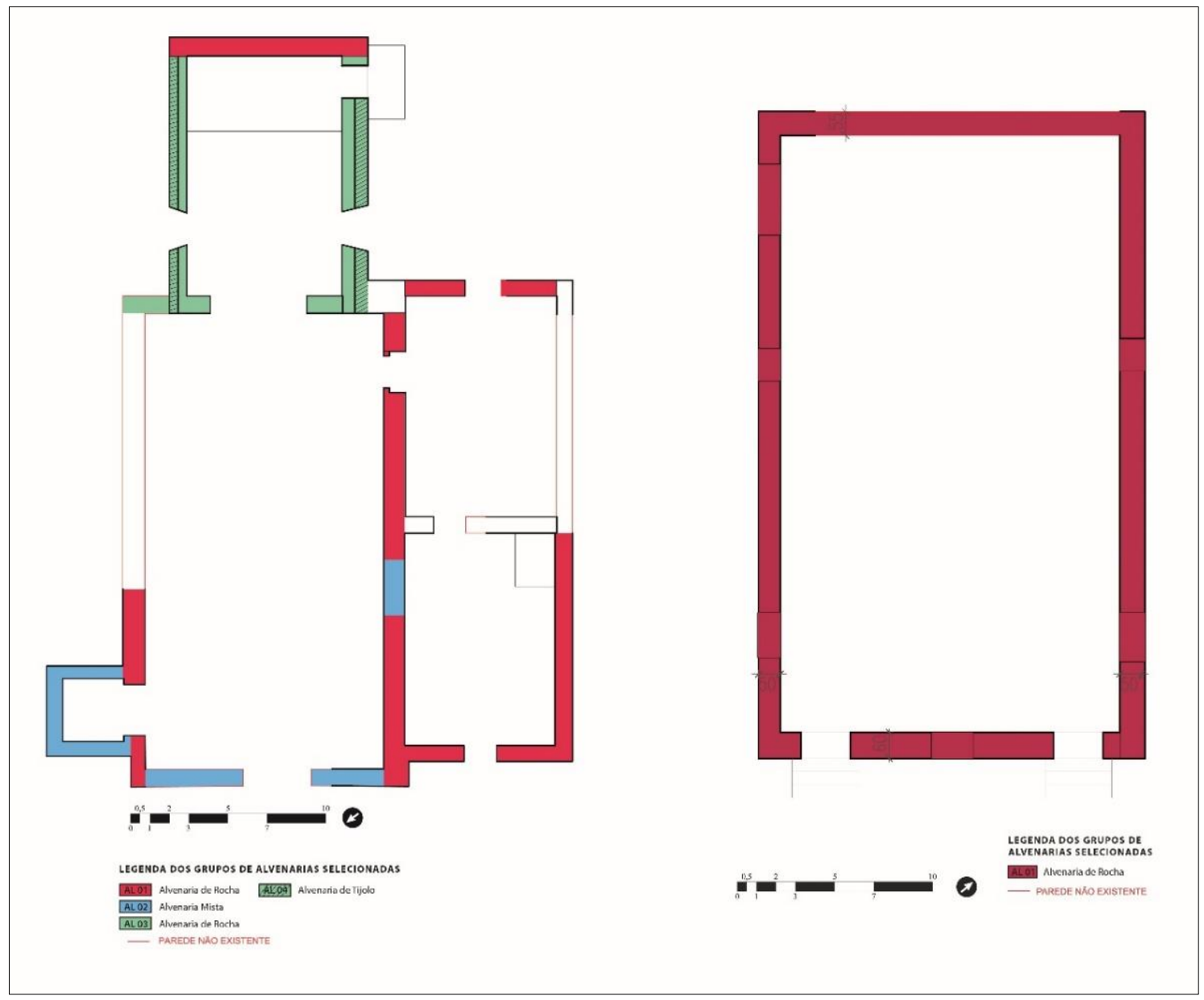

Figura 10. Plantas baixas da Igreja de Nossa Senhora dos Prazeres e sua Casa paroquial com indicação das alvenarias selecionadas para a realização de análises mais detalhadas, especificamente, as alvenarias que apresentaram mais de 10 metros lineares. Fotografia e figura elaborada pela autora (2018). 


\subsection{LEVANTAMENTO QUANTITATIVO DOS MATERIAIS}

Dentre uma série de técnicas disponíveis na Arqueometria, algumas foram escolhidas para auxiliar na resposta aos questionamentos levantados durante o processamento de dados. A escolha das técnicas está associada aos objetivos pretendidos e aos recursos disponíveis ao pesquisador. Os métodos aqui selecionados foram: exame ótico macroscópico e fluorescência por raios-X (FRX).

\subsubsection{Exame Óptico Macroscópico}

O exame ótico macroscópico é uma técnica não destrutiva, de fácil realização, e que não exige que a amostra sofra quebra caso não seja necessário. Toda superfície do material é observada a olho nu com auxílio de Lupa, que auxilia na caracterização desses materiais. Essa caracterização pode ser realizada com base na tabela de Compton (1962), considerando aspectos relacionados à granulometria, coloração, grau de seleção, esfericidade e arredondamento dos grãos, por exemplo, que podem ser importantes para a constatação das fases construtivas.

Observando a granulometria, pode-se identificar os tamanhos dos grãos presentes nas amostras. É uma técnica de baixa exatidão, mas que contribui para a caracterização do material no reconhecimento das variações na composição desses materiais coletados. A coloração pode indicar as possíveis matérias-primas utilizadas na preparação do material, no caso dos tijolos e rejuntes. O grau de seleção auxilia na identificação dos grupos de materiais e como as matérias-primas foram associadas. A esfericidade e arredondamento dos grãos podem dar informações sobre o transporte dos materiais e sobre a sedimentação. Assim, a partir desses atributos é possível conhecer aspectos que determinam o local de origem da matéria-prima.

As observações dessas informações permitem identificar variações nas composições dos diferentes tipos de materiais e nas amostras de mesmo material, apesar do método não apresentar uma exatidão sobre a constituição e origem deles.

Baseado nas análises macroscópicas, -confirmou-se a existência dos dois tipos de tijolos predefinidos nas análises dos materiais: o tipo 1, com as pastas de moderada a bem selecionada, bem homogeneizadas e de coloração vermelho escuro; e o tipo 2, com uma pasta mal homogeneizada, pobremente selecionada e com a coloração em vermelho claro.

A partir das informações coletadas, observou-se três tipos de rejuntes, apesar de não possuírem diferenças tão marcantes. O primeiro tipo foi percebido na AL 01. Pobremente selecionada, essa pasta se apresenta mal homogeneizada; com pequenos pedaços de cal; não é friável; mas é de fácil quebra. O segundo tipo, o AL 05, tem uma pasta moderada na sua seleção, porém apresenta uma considerável quantidade de cal de má homogeneização e mais resistente. E o terceiro tipo está nas alvenarias AL 06 e AL 07, que são bem homogeneizadas; com presença de cal; com a pasta bastante friável; e quebra sem nenhuma dificuldade.

\subsubsection{Fluorescência por Raios $-X$}

A fluorescência por raios - X (doravante FRX) tem propósitos qualitativos e quantitativos, que foram baseados nas medições das intensidades dos raios- $\mathrm{X}$ característicos emitidos pelos elementos presentes nas amostras quando estimuladas por partículas de elétrons, prótons e íons obtidos (Melo Júnior, 2007). Ao ser 
estimulado, cada elemento libera uma energia característica que pode ser reconhecida e uma intensidade de emissão, a qual identifica a quantidade desse elemento na amostra. A FRX não é destrutiva e, por possibilitar análises de vários elementos químicos de forma rápida e de baixo custo, pode ser aplicada em várias áreas que necessitam conhecer e quantificar elementos químicos (Freitas, 2015). Todas as amostras coletadas nas alvenarias, sendo elas as rochas, os rejuntes e tijolos, foram submetidas ao exame e analisadas no Núcleo de Metrologia Arqueológica e Patrimônio Cultural, localizado na UFPE. Foram realizadas três medidas e, para cada amostra, as medições duravam 30s

A composição química observada nas análises do FRX indica que as rochas utilizadas nas estruturas são análogas. E, apesar dessas rochas possuírem variações nos formatos e nos trabalhos em superfície, através do FRX fica comprovado que elas possuem as mesmas características químicas. As diferenciações entre o percentual de Cálcio, Alumínio e Silício nas amostras são pequenas, apresentando uma quantidade significativa de Cálcio e pequenas quantidades de Silício, Alumínio, Ferro e Potássio. Com essa composição, concluiu-se que todas as rochas utilizadas nos edifícios são calcárias. O Calcário é uma rocha sedimentar, sendo o Cálcio um de seus elementos constituintes mais comuns. Além disso, essas rochas estão em 3 - 4\% da crosta terrestre e, portanto, consideradas rochas ígneas (Almeida \& Sampaio, 2008).

Os tijolos apresentaram a mesma composição química, com mínimas variações nos componentes auxiliares. A partir desse resultado, ficou comprovada que a diferença entre os tijolos identificados como Tipo 01 e Tipo 02 está apenas na sua superfície. O tijolo tipo 01 está em praticamente toda a Igreja e Casa paroquial; não possui arestas; tem um acabamento enrugado; e tem coloração vermelho escuro. O tijolo da parede 13B é a única amostra do Tipo 02, que é definido como tijolo regular; com arestas vivas; e tem coloração vermelho claro.

Os rejuntes analisados no exame de FRX apresentaram resultados que indicam a existência de três tipos. Para chegar a essa conclusão, foi necessário identificar a existência de uma constância entre seus resultados e, assim, associar os rejuntes que possuíam os mesmos valores. No Tipo 01 os materiais são dosados de forma moderada, o que significa que cal e areia possuem a mesma medida e a argila, a metade dos outros materiais. O Tipo 02 tem em sua pasta quase que predominantemente cal e areia e se excluir a argila, o traço desses dois elementos construtivos fica de 1:1. Já o Tipo 03 também possui praticamente apenas cal e areia, e se excluir a argila, o traço fica $2: 1$.

Tabela 5. Resumo dos traços dos rejuntes identificados através da FRX (Elaborada pela autora, 2018).

\begin{tabular}{ccc}
\hline REJUNTES & TRAÇO & PAREDES \\
\hline TIPO 1 & $2: 2: 1$ & $04,8,10,11,12$ \\
\hline TIPO 2 & $5: 4: 0,5$ & $01,02,07$, Casa paroquial \\
\hline TIPO 3 & $7: 3: 0,5$ & $09,13,13 \mathrm{~B}, 14,15$ \\
\hline
\end{tabular}

Com base nos resultados obtidos, evidenciou-se que em cada tipo de rejunte houve a diminuição da utilização de argila, prevalecendo o uso de cal e areia. Pode ser uma indicativa da utilização de materiais locais e de fácil acesso. As lavras de argila estão a certa distância da Igreja Nossa Senhora dos Prazeres e, por ser necessária uma grande quantidade de rejunte para o assentamento dos materiais, optou-se por utilizar cal e areia em maior proporção. 


\section{CONSTATAÇÕES A PARTIR DO LEVANTAMENTO FÍSICO DA EDIFICAÇÃO E DOS DADOS QUÍMICOS COLETADOS DAS ALVENARIAS}

A partir do levantamento qualitativo e quantitativo, e no ímpeto de encontrar tal resposta, surgem duas hipóteses e em cada uma se determinou três diferentes etapas do processo construtivo. Com o levantamento das alvenarias e dos materiais, identificou-se a existência de 7 tipos de alvenarias, no qual 4 foram selecionadas. A seleção das alvenarias AL 01, AL 05, AL 06 e AL 07 configura uma hipótese de fase construtiva a partir dos materiais. A segunda hipótese é determinada a partir dos três tipos de rejuntes identificados nas análises realizadas pelo exame macroscópico e pelo FRX.

\section{PRIMEIRA HIPÓTESE CONSTRUTIVA}

Com o levantamento qualitativo dos materiais, a construção da Igreja Nossa Senhora dos Prazeres e da Casa paroquial poderia ter sofrido um crescimento a partir da presença dos tijolos e da cantaria. A cantaria pode ser vista em algumas partes em ambos os edifícios - como em portais, janelas e alguns detalhes de adornos -, porém muito já está em situação de desmoronamento: seus pedaços podem ser observados sobre o solo. Para o levantamento e cronologia, foram utilizadas apenas as paredes estruturais. As questões mais estilísticas não foram escolhidas como variáveis nesta pesquisa.

Posto isso, a Figura 11 a seguir representa a possível cronologia a partir dos materiais. Para chegar às fases construtivas, foi levado em consideração os materiais utilizados e suas especificações, como: formato, acabamento de superfície, coloração, dimensões existentes em cada parede e suas paginações. As paginações revelaram a organização dos materiais nas paredes, que, inicialmente, tinham apenas rochas e que, posteriormente, se passou a utilizar tijolos.

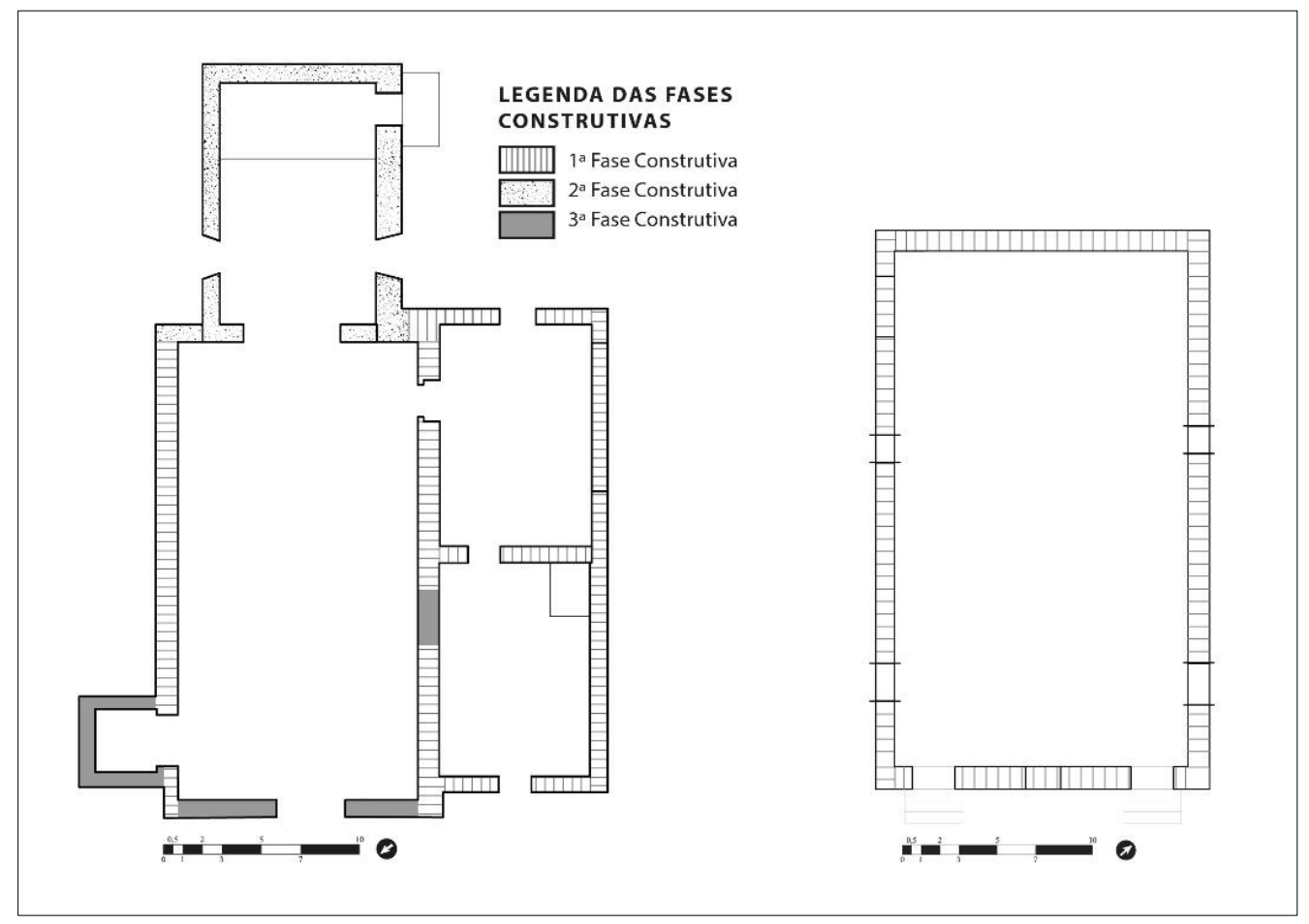

Figura 11. Representação da primeira hipótese das fases construtivas baseada no levantamento dos materiais. Fotografia e figura elaborada pela autora (2018). 
A primeira fase construtiva está localizada no corpo principal da Igreja e foi a partir dela que se deu o seu crescimento. A Igreja possui rochas de formatos irregulares, com tijolos do tipo 01, que são utilizados nas portas e para reparar pequenos buracos nas paredes, que pode ter acontecido posterior a sua construção. Por possuir a mesma técnica construtiva, materiais e paginações, a hipótese é de que a Casa paroquial teria sido construída no mesmo período (1656) que a Igreja. A segunda fase construtiva está localizada no altar mor da Igreja, que tem um formato retangular e de largura um pouco mais estreito em comparação a nave central; e possui paredes grossas de sustentação para o arco cruzeiro da Igreja. Nessas paredes são encontradas rochas com trabalho em superfície em formatos de polígonos irregulares e tijolos do tipo 1 nos portais. A terceira fase construtiva está presente nas fachadas frontais; na torre sineira, onde está o batistério; e no fechamento de uma porta que dava passagem da sacristia à nave central. Essas paredes possuem tijolos tipo 1, horizontalmente organizados em fiadas, dividindo a paginação entre as rochas. Os tijolos do tipo 1 estão em pedaços ou inteiros, porém com formato irregular.

\section{SEGUNDA HIPÓTESE CONSTRUTIVA}

A partir do levantamento quantitativo dos rejuntes, uma nova hipótese ficou evidente a partir do percentual de cada elemento químico apresentado nos resultados da análise macroscópica e FRX. Esse percentual indica a quantidade de cada material utilizado na mistura da pasta, ou seja, o traço do rejunte. O rejunte, diferentemente da rocha e do tijolo, não é reutilizável, o que indica que provavelmente ele foi utilizado apenas uma vez nos edifícios. Nesta hipótese, as divisões por alvenarias não são utilizadas, e sim a denominação de todas as paredes, pois as variações dos traços dos materiais das pastas desenharam uma nova possibilidade de fases construtivas, que podem ser observadas a seguir na Figura 12.

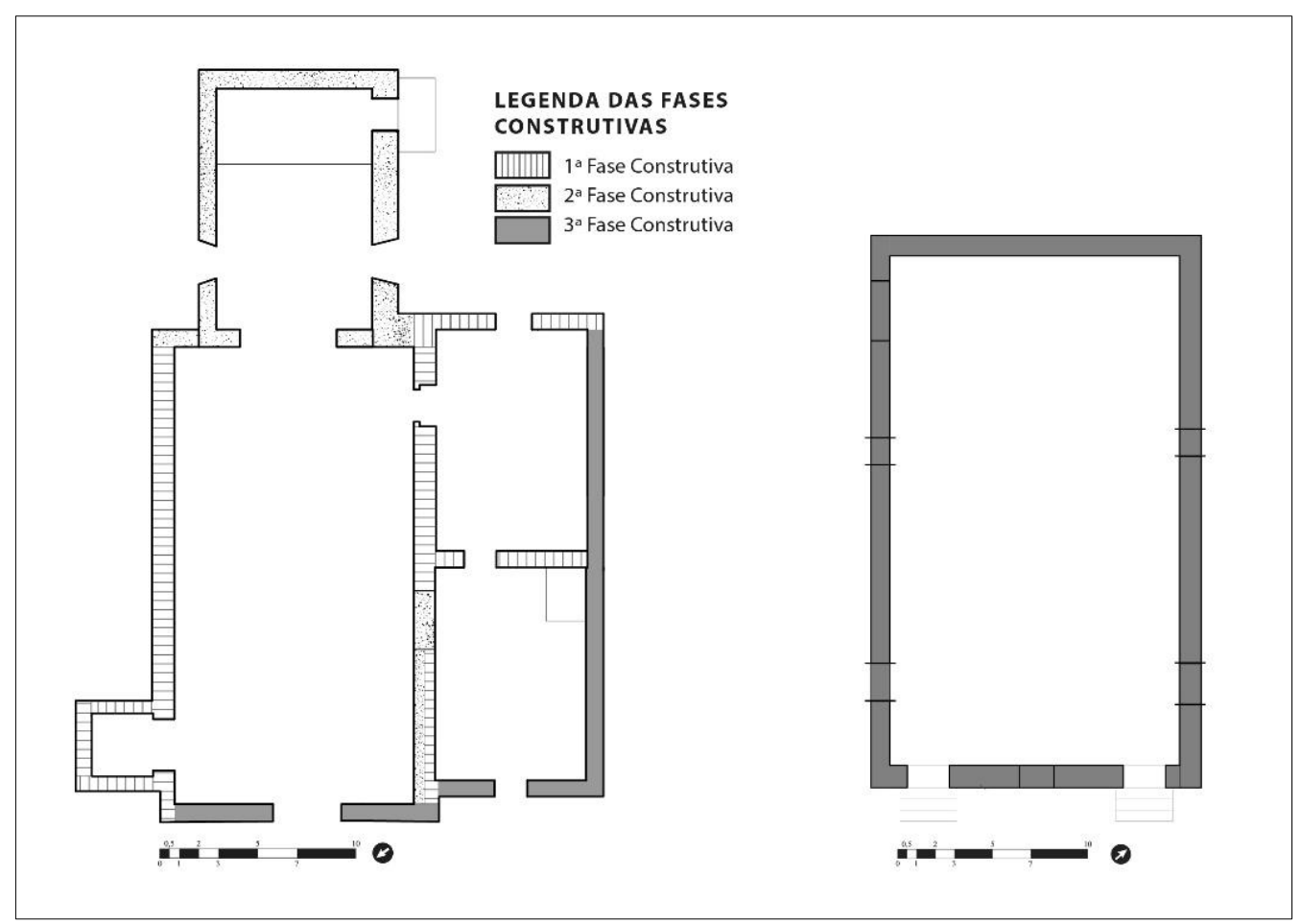

Figura 12. Representação da segunda hipótese das fases construtivas baseada nas análises dos rejuntes analisados macroscopicamente e pela Fluorescência de raios - X Fotografia e figura elaborada pela autora (2018). 
A primeira fase construtiva está presente nas paredes que constituem o corpo principal da Igreja, sendo composta pela sacristia, nave central e torre sineira. As paredes possuem o rejunte tipo 01 e diferentes técnicas construtivas na sua estrutura, com a utilização de rochas e tijolos. O rejunte dessa fase possui bolos de cal em sua pasta, evidenciando a má homogeneização e a fácil quebra, apesar da pasta não se apresentar friável. A segunda fase construtiva está presente no altar mor e possui o rejunte tipo 3. A pasta apresenta uma boa homogeneização, apesar de apresentar a presença de bolos de cal, e é bastante friável. A terceira fase construtiva está presente na fachada frontal da Igreja, que compreende a entrada da sacristia e uma parte da parede da fachada lateral direita. Essa terceira fase teria surgido a partir da necessidade de reformar suas paredes frontais. A Casa paroquial teria sido construída nessa fase, pois possui o mesmo traço de materiais do rejunte tipo 2. Essa construção apresenta uma grande quantidade de cal na sua pasta, é má homogeneizada e mais resistente à quebra.

Através de todo o levantamento dos dados e suas análises, constatou-se a possibilidade de duas hipóteses responderem ao questionamento de quantas fases construtivas existiam nas edificações. Uma hipótese não anula a outra, porém, a partir de alguns aspectos, tanto históricos quanto materiais, uma das hipóteses se mostrou mais coerente. Para chegar a esse resultado alguns aspectos devem ser pontuados:

As análises do FRX confirmaram que os tijolos utilizados na construção possuem as mesmas características químicas em todos os edifícios, divergindo com as análises macroscópicas, que observaram algumas diferenciações nas colorações e nas pastas, além dos diferentes formatos observados no levantamento quantitativo. Tanto as rochas quanto os tijolos são organizados a partir de uma mesma técnica construtiva, com paginações em linhas horizontais, variando apenas na utilização dos tipos de materiais. O reaproveitamento dos materiais fica evidente no altar mor (parede 15) quando se verifica que sua paginação é análoga à parede 04 da sacristia, ambas em momentos construtivos diferentes, de acordo com a $2^{\circ}$ hipótese de fases construtivas aqui sugeridas.

As duas técnicas utilizadas constataram que apenas os rejuntes possuíam variações e ambas apresentaram a existência de três tipos de rejuntes nas duas edificações. A primeira técnica observou a consistência e resistência à quebra por martelo de geólogo, além dos aspectos físicos visto a olho nu e dos atributos da tabela de Compton (1962 apud Matos, 2009, p. 77). A segunda técnica verificou a sua composição química. Para chegar à segunda hipótese, foi necessário correlacionar os dados obtidos a fim de identificar as paredes em que esses dados convergiam. Além disso, diferentemente dos materiais construtivos, os rejuntes não são materiais reutilizados em uma construção. A pasta dos rejuntes é formada por aglomerantes e água. Ao endurecer, ela auxilia na junção dos materiais e sua retirada só é possível com a quebra da pasta, o que assegura a segunda hipótese, deixando a primeira hipótese preterida.

Desse modo, a $2^{\circ}$ hipótese apresenta maior coerência diante das possibilidades de elaboração das fases construtivas da Igreja Nossa Senhora dos Prazeres e sua Casa paroquial. Mesmo apresentando paginações e materiais diferentes, só puderam ter suas fases construtivas verificadas através dos rejuntes.

\section{CONSIDERAÇÕES FINAIS:}

ASSOCIAÇÃO ENTRE CONTEXTO HISTÓRICO E ANÁLISE ARQUEOLÓGICA DOS MATERIAIS CONSTRUTIVOS

A invasão holandesa e posteriormente sua capitulação trouxe transformações políticas e econômicas para a Vila de Olinda, que geraram transtornos econômicos para os senhores de terras cultivadores de Cana-deaçúcar, como Fernandes Vieira. O receio de novos ataques à capitania de Pernambuco, onde possuía muitos 
patrimônios, fez Fernandes Vieira realizar pedidos de maior proteção à Vila de Olinda em 1654. Tendo seus pedidos negados, em 1656, ele constrói uma Igreja em uma área afastada da Vila de Olinda, como uma manobra para demarcar seu território. A Igreja estava localizada em cima de um morro que permite uma boa visibilidade do entorno e, portanto, estava situada em uma área estratégica, cujo objetivo era proteger sua propriedade de possíveis ataques.

O fenômeno religioso nesse contexto assegurou o domínio do território. Inicialmente, a Igreja Nossa Senhora dos Prazeres pertencia à propriedade rural de Fernandes Vieira, mas posteriormente, passou aos cuidados da Igreja Católica, o que aponta a capacidade de modificação para adaptar o território à afirmação de poder, na medida em que a Igreja se desenvolveu e passou a se reestruturar para atender às demandas sociais.

Sabendo da intenção em ocupar o território da Freguesia de Maranguape e com base nos dados materiais, a identificação das fases tecnológicas contempla os momentos históricos ocorridos durante a construção e a elevação à matriz. As fases construtivas identificam as mudanças ocorridas na edificação a partir da ideia de crescimento da estrutura, como nas mudanças de aspecto físico e no advento da construção da Casa Paroquial, quando foi necessário dar moradia aos párocos. Tais fases são transformações ocorridas com planejamento e execução para o surgimento de um novo estado para o conjunto de edifícios em questão. Deste modo, associando as fases construtivas com os momentos históricos, temos:

A primeira fase construtiva da Igreja ocorreu em 1656, quando possivelmente iniciou sua construção, como foi representada na $2^{\circ}$ hipótese proposta. Nessa fase, a Igreja foi construída em tamanho razoável, em rochas calcárias e com pouca presença de tijolos, utilizados apenas em lugares pontuais, como portas e janelas. Mesmo com o cuidado em organizar os materiais horizontalmente, as alvenarias apresentam um aspecto de descuido na utilização dos rejuntes, que são utilizados em grande quantidade, além de apresentar uma pasta mal homogeneizada, que apresenta bolos de cal.

Em 1691, a Igreja Nossa Senhora dos Prazeres recebeu o título de curato, que indica quando uma determinada área pode se tornar uma freguesia. Aqui, seria o início da segunda fase construtiva, momento em que há a adesão do altar mor, construído por materiais reutilizados da própria Igreja. Além disso, uma porta que dava acesso da sacristia para a nave central foi fechada e parte da parede da nave central foi engrossada com tijolos e argamassa. O título de curato indica que a região já possuía uma quantidade significativa de fiéis frequentadores, assim as modificações na estrutura possivelmente tenham ocorrido antes de receber o título, porém a datação precisa não foi possível determinar.

Em 1719, a Igreja é elevada à Matriz, para isso ela precisou atender uma quantidade considerável de fiéis, ou seja, está diretamente ligada à dinâmica daquela área. Nesta terceira fase, a Igreja recebeu uma reforma na sua fachada frontal e em uma das paredes laterais, além da construção da Casa paroquial, já que, de acordo com o Código de Direito Canônico (1993), no artigo Cân. 533, parágrafo primeiro, “O Pároco está obrigado a residir na Casa paroquial junto à Igreja...”. Os ornamentos, como as cantarias, teriam sido utilizados a partir deste momento, em que a igreja recebeu o título de Matriz e precisou oferecer aos Párocos moradia.

As fases construtivas apresentaram dados que correspondem aos momentos históricos de seu crescimento de capela à Igreja matriz. Os materiais se comportaram de modo semelhante nas duas estruturas, tanto no preparo quanto na aplicação das alvenarias, em que o rejunte foi o fator determinante para evidenciar as fases construtivas. Contudo, este trabalho não pretende impor uma verdade absoluta e sim abrir o leque de possibilidades para as possíveis interpretações de edifícios históricos através dos seus dados materiais. O método utilizado tem como objetivo auxiliar pesquisas em edifícios históricos ou culturais através da Arqueologia para 
conhecer o modo de construir das comunidades, além de fornecer dados que podem responder questionamentos não respondidos a partir de fontes documentais.

\section{REFERÊNCIAS BIBLIOGRÁFICAS}

Almeida, Salvador Luiz Matos de., \& Sampaio, João Alves. (2008). Calcário de Dolomito. Rochas e Minerais Industriais - CETEM, $2^{\mathrm{a}}$ edição.

Andrade, Manuel Correia de. Economia Pernambucana do Século XVI. (2003). Recife: Editora Universitária da UFPE.

Araújo, Plínio., Camurati, Paulo., \& Santana, Aneide. (1993). Projeto de Restauração da Matriz de Maranguape: Uma Proposta Histórica. Paulista: Prefeitura da cidade do Paulista.

Azevedo, Dermi. (2004). A Igreja Católica e seu papel político no Brasil. Estudos Avançados. Vol.18 No 52 São Paulo, set./dez.

Basalla, George. (1990). La Evolución de la Tecnología. Editorial Crítica, Barcelona, (p. 13 a 249).

Bötticher, Karl. (1852). Die Tektonik der Hellenen, Potsdam: Ed. Ferdinand Higel.

Choisy, Auguste. (1997). El Arte de Construir en Bizancio. Madrid: Ed. Cehoup e Instituto Juan de Herrera.

Choisy, Auguste. (1999). El Arte de Construir em Roma. Madri: Ed. Cehoup e Instituto Juan de Herrera.

Choisy, Auguste. (2006). El Arte de Construir en Egipto. Madrid: Ed. Cehoup e Instituto Juan de Herrera.

Código de Direito Canônico. (1983). Promulgado por S.S o Papa João Paulo II. Versão portuguesa, $4^{\circ}$ edição revista - conferência episcopal portuguesa - Lisboa.

Eiroa, Jorge Juan., Gil, Jose Alberto Bachiler., Pérez, Ladislao Castro., \& Maurandi, Joaquín Lomba. (1999). Nociones de Tecnología y Tipología em Prehistoria. Ariel, Barcelona.

Freitas, Yuri Menezes. (2015). Azulejos Portugueses dos séculos XVII e XVII em Pernambuco: Patologias e caracterização tecnológica. Dissertação de mestrado, Programa de pós-graduação em Arqueologia e Preservação Patrimonial, Universidade Federal de Pernambuco. Recife.

Galvão, Tácito Luiz Cordeiro., \& Gomes, Rosângela Oliveira. (2016). O processo histórico da formação do município de Paulista. Recife: Biblioteca Pernambucana de história municipal.

Gama, Ruy. (1986). A tecnologia e o trabalho na história. São Paulo: Nobel: Editora da Universidade de São Paulo.

Gomes, Geraldo. (1998). Engenho e Arquitetura. Recife: Fundação Gilberto Freyre, $2^{\circ}$ edição.

Janeira, Ana Luísa. (1972). Ruptura epistemológica, corte epistemológico e ciência. Análise Social, Lisboa, sér. 2, 9 (34) abr.- jun. 629-644.

Leroi-Gouham, André. (1984). Evolução e Técnicas I: o homem e a matéria. Edições 70. Lisboa.

Lima Júnior, Genival Costa de Barros. (2012). Identificação das influências construtivas e culturais nas construções praieiras no Nordeste do Brasil. Dissertação de mestrado. Programa de pós-graduação em História, Universidade Federal de Pernambuco. Recife.

Manonni, Tiziano. (2005). Arqueologia da produção arquitetônica: As técnicas de construção. Revista Arqueologia da Arquitetura, v. 4, p. $11-19$.

Matos, Manuela Xavier Gomes de. (2009). Análises de Estruturas em Alvenaria: modelo para análise e identificação dos processos construtivos e das etapas de execução de uma edificação de valor histórico/ cultural. Dissertação de mestrado, Programa de pós-graduação em Arqueologia e Preservação Patrimonial, Universidade Federal de Pernambuco. Recife. 
Mello, Evaldo Cabral de. (1976). Uma relação dos engenhos de Pernambuco em 1655. In: RIAP, Vol. XLVIII.

Mello, Evaldo Cabral de. (2007). Olinda Restaurada: guerra e açúcar no Nordeste, 1630 - 1654. São Paulo: Editora 34.

Mello, Evaldo Cabral de. (2008). Rubro Veio: o imaginário da restauração pernambucana. São Paulo: Alameda, $3^{\circ}$ edição.

Mello, José Antônio Gonsalves de. (2000). João Fernandes Vieira: Mestre - de - Campo do terço da Infantaria de Pernambuco. Lisboa: Comissão Nacional para as comemorações dos Descobrimentos portugueses.

Melo Júnior, Ariston. S. (2007). Análise quantitativa do material particulado na região de campinas através das técnicas de microfluorescência de raios-X e reflexão total usando radiação síncrotron. Tese de Doutorado em Química, Unicamp, São Paulo.

Mori, Klára Kaiser. (1996). Brasil: urbanização e fronteiras. Tese de doutorado, Programa de pós-graduação em Estruturas Ambientais Urbanas, Faculdade de Arquitetura e Urbanismo da Universidade de São Paulo, São Paulo.

Müller, Karl Ottfried. (1878). Handbuch der Archaeologie der Kunst. Stuttgart: Ed. Albert Heitz.

Mumford, Lewis. (1986). Arte e Técnica. Edições 70. Lisboa.

Nascimento, Eliane Maria Vasconcelos do. (2008). Olinda: uma leitura histórica e psicanalítica da memória sobre a cidade. Tese de doutorado, Programa de pós-graduação em História Social, Universidade Federal da Bahia. Salvador.

Pereira, José Carlos. (2008). Religião e Poder: Os símbolos do poder sagrado. Revista eletrônica de Ciências Sociais. Ano 2, v. 3.

Schwartz, Stuart B. (1988). Segredos Internos: engenhos e escravos na sociedade colonial 1550-1835. São Paulo: Companhia das Letras.

Vargas, Milton. (1994). Para uma Filosofia da Tecnologia. São Paulo. Editora Alfa.

Vieira, Glena Salgado. (2010). Decadência e expansão no litoral norte de Olinda (1654- 1710): a Freguesia de Maranguape. Dissertação de Mestrado em Arqueologia e Preservação Patrimonial, Universidade Federal de Pernambuco, Recife.

Viollet-le-Duc, Eugène Emmanuel. (1996). La Construción Medieval. Madri: Ed. Instituto Juan de Herrera. Em virtude da especificidade e da notoriedade do tema, o artigo foi publicado depois isoladamente como livro e possui diversas edições. 